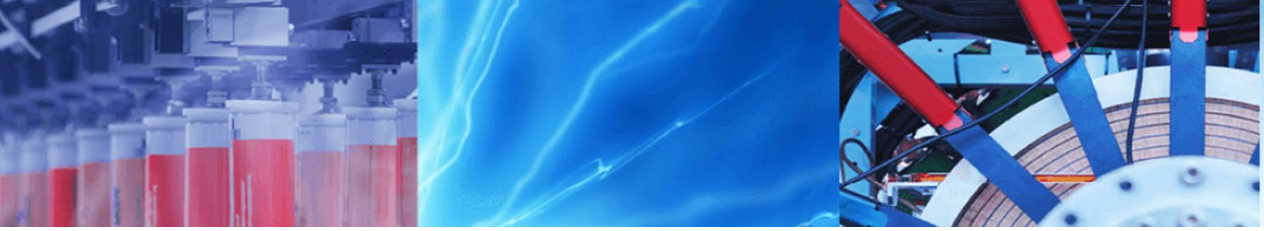

Research Article

\title{
Long-term changes in water mineral concentrations and their influence on sediment water content in a shallow lake
}

\author{
Takehiko Fukushima $^{1,2}$ (D) Shunsuke Komuro ${ }^{1} \cdot$ Tatsumi Kitamura $^{1} \cdot$ Yumi Nagahama $^{1} \cdot$ Bunkei Matsushita $^{2}$
}

Received: 19 March 2020 / Accepted: 19 June 2020 / Published online: 1 July 2020

(c) Springer Nature Switzerland AG 2020

\begin{abstract}
During the last four decades, substantial changes have been observed not only in tripton concentrations but also in other limnological parameters in Lake Kasumigaura, a shallow eutrophic lake. A previous study reported that tripton concentration showed a positive correlation with sediment water content (WC) and a negative one with sediment ignition loss. To explain the changes in sediment WC, we conducted an analysis of the changes in mineral concentrations and sediment WC during 1979-2016 to determine their relationship. High mineral concentrations in water throughout the lake were observed in the latter half of the 1990s and higher WC in sediments followed with a time lag of a few years, resulting in significant correlations. The relationship between them was confirmed in laboratory experiments that indicated swelling of sediments (slowdown of sediment compaction) by the addition of $\mathrm{NaCl}$ into the water-sediment system. In contrast, significantly lower SS concentrations in overlying waters observed in higher mineral conditions were similar to previous studies. The significantly low annual precipitation during 1994-1997 probably caused high $\mathrm{Na}^{+}$and $\mathrm{Cl}^{-}$concentrations in the lake waters in the latter half of the 1990s. The combined influence of sea-spray aerosol and evaporation was suspected to be the cause of high salt concentrations. The intrusion of salty water through the downstream gate and/or surrounding construction structures was another possibility.
\end{abstract}

Keywords Shallow lake $\cdot$ Sediment $\cdot$ Mineral ions $\cdot$ Swelling $\cdot$ Precipitation

\section{Introduction}

In shallow lakes where sediment resuspension occurs frequently, tripton (non-planktonic suspended solids: SS) affects the physical, chemical and biological processes of the lakes [1,2]. Over the last four decades, substantial changes in tripton concentrations have been observed in Lake Kasumigaura, a shallow eutrophic lake. Tripton concentration showed a positive correlation with sediment water content (WC) and a negative one with sediment ignition loss (IL) with a few years' delay [3]. Results of hydraulic experiments with sediment samples [4] were in agreement. The subsequent question arises as to why the sediment properties changed. In the latter half of the 1990s, i.e., a few years before the tripton peak, high concentrations of mineral ions (salinity) were detected in water, particularly $\mathrm{Na}^{+}$and $\mathrm{Cl}^{-}$. Is there any causal relationship between them?

Salinity-induced aggregation and flocculation of suspended matter in water have been described in estuaries with high salinity [5-7]. In the case of dissolved matter, Sholokowiz [8] found in laboratory experiment that

Electronic supplementary material The online version of this article (https://doi.org/10.1007/s42452-020-3119-z) contains supplementary material, which is available to authorized users.

Takehiko Fukushima, fukushima.takehik.fu@u.tsukuba.ac.jp | ${ }^{1}$ Ibaraki Kasumigaura Environmental Science Center, 1854 Okijyuku, Tsuchiura, Ibaraki 3000023, Japan. ${ }^{2}$ Faculty of Life and Environmental Sciences, University of Tsukuba, 1-1-1 Tennoudai, Tsukuba, Ibaraki 3058572, Japan. 
the amount of flocculated matter increased as salinity increased from 0 to $15-20$. The significant decrease in surface water turbidity under both fluctuating and constantly brackish water indicated that these processes were also important within lower salinity ranges, e.g., up to $5 \mathrm{mmol}$ $\mathrm{Cl}^{-} \mathrm{dm}^{-3}$ (around $175 \mathrm{mg} \mathrm{dm}^{-3}$ ) [9]. In contrast, Shiraki [10] conducted experiments on the swelling properties of clay-water systems, and reported that $\mathrm{NaCl}$ could result in higher swelling expansions compared to other salts. There have also been experimental and/or modelling studies analyzing the swelling rates of clays in different solution conditions [11, 12]. Recently, Zhu et al. [13] performed two sets of experiments to examine the flocculation and settling properties of low- and high-concentration sediment suspensions. The influences of salinity content and concentration on the properties were also analyzed. Thus, an influence of salinity changes on water and sediments is expected, but its manifestation in lakes has not yet been clarified.

Meanwhile, global warming and climatic change could affect lake hydrological conditions and thereby the lake water environment in the near future. Possible changes in meteorological parameters and ionic states in lake water would have a heavy impact on lake water quality and ecosystem.

In order to help to solve the above-mentioned questions, the purposes of the present study are (1) to clarify the long-term changes in mineral ions and sediment properties by analyzing 38 years of data obtained in Lake Kasumigaura, a shallow eutrophic lake, and determine their relationships; (2) to determine experimentally the relationships of mineral ion concentrations with sediment water content and turbidity in overlying water as indicated by the field data; and (3) to analyze the reasons for the changes in mineral ions in the lake. Thus, we think that the innovation of this study is to elucidate the relationship between lake salinity and sediment water content based on the analysis on long-term monitoring data and laboratory experiments.

\section{Materials and methods}

\subsection{Study site}

Lake Kasumigaura with a surface area of $171 \mathrm{~km}^{2}$ (Fig. 1) is the second largest lake in Japan after Lake Biwa. Due to its shallowness (mean depth of $3.4 \mathrm{~m}$; maximum depth of 7.0 $\mathrm{m}$ ) and the intensive human activities in the watersheds [14], the lake is characterized by high turbidity (Secchi depth: 0.69 m during 1979-2016 at St. 1) and eutrophic conditions (total phosphorus [TP]: $0.084 \mathrm{mg} \mathrm{I}^{-1}$, total nitrogen [TN]: $1.01 \mathrm{mg} \mathrm{I}^{-1}$ ). Its $1426-\mathrm{km}^{2}$ catchment area

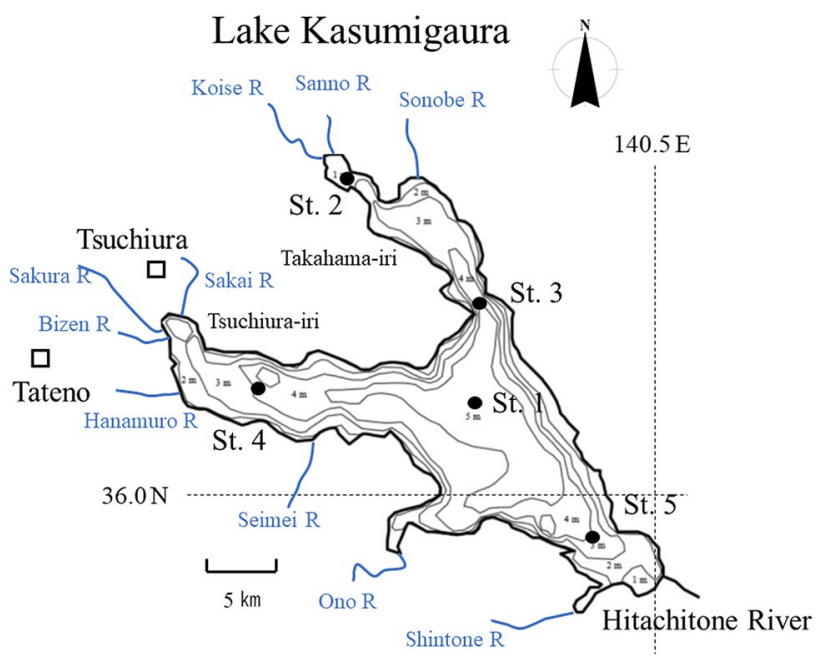

Fig. 1 Lake Kasumigaura and sampling stations. Solids circles indicate water quality measurements and open squares represent meteorological measurements

(excluding the lake) consists of about $30 \%$ forests, $25 \%$ paddy fields, $25 \%$ ploughed field, $10 \%$ residential areas, and $10 \%$ other.

The apparent water residence time of the lake is about 0.55 years. Diurnal stratification is sometimes formed under a weak-wind condition [15], but vertical stratification is easily destroyed by strong winds due to its shallow depth [16]. More than twenty rivers flow into the lake and main ten rivers were shown in Fig. 1. The sum of these ten rivers' watersheds covers around $77 \%$ of the whole basin. Water tends to flow through the lake from northwest to southeast, to the effluent Hitachitone River. The lake was originally a brackish-water lagoon, with an indirect connection to the Pacific Ocean via the Tone River. The Hitachtone River gate was constructed in 1963 at the confluence of the Tone and Hitachtone Rivers (about $30 \mathrm{~km}$ downstream of the lake outlet) to prevent salt-water intrusion and manage the water level for water utilization and floodcontrol [14]. The water salinity has since declined. The present state of major mineral ions indicates that the lake is in a freshwater condition (Supplementary Table 1).

Due to its shallowness, processes related to watersediments interactions such as sediment resuspension, release of dissolved matter from sediments, etc. play a large role in dynamics of substances [17-19]. Relatively rapid penetration of radiocesium into deeper layers of sediment (around $20 \mathrm{~cm}$ ) in the central part of the lake was observed a few years after the 2011 Fukushima nuclear accident [20]. In addition, Otsubo et al. [21] reported relatively large regional differences in physical properties (WC, IL, grain size, specific density) of Lake Kasumigaura surface sediments (up to $30 \mathrm{~cm}$ depth) based on sediment core samples taken at 25 sites. Sediments with higher WC and 
IL (also, smaller grain size and lower specific density) were located in the deeper parts of the lake (Sts. 1 and 3); in contrast, lower WC and IL were observed in the shallower parts near the main inflow rivers (Sts. 2 and 4 ) and the outflow river, i.e., the Hitachitone River (St. 5). A likely reason for high sand percentage observed near the outflow river is that the strong water exchange and bottom shear stress in this area did not allow fine grain sediments to accumulate leaving the heavier coarse fractions before the Hitachitone River gate was constructed in 1963.

\subsection{Database}

For the analysis, we used the data on monthly water quality and yearly sediment quality at several stations (Fig. 1) for the period 1979-2016 which were collected by the Kasumigaura River Office (KRO) belonging to the Ministry of Land, Infrastructure and Transport (MLIT). KRO took water samples at $0.5 \mathrm{~m}$ below the water surface because nearly uniform vertical profiles of water quality parameters were usually observed [16]. Three or more sediment subsamples up to $10-\mathrm{cm}$ deep were taken in Aug by bottom grab samplers (Ekman-Birge type) and mixed to create one composite sample at each location and time.

Of the 50 water quality parameters recorded in the KRO database as explained in Fukushima et al. [3], the focus in this study was on major inorganic cations and anions (sodium $\left[\mathrm{Na}^{+}\right]$, potassium $\left[\mathrm{K}^{+}\right]$, magnesium $\left[\mathrm{Mg}^{2+}\right]$, calcium $\left[\mathrm{Ca}^{2+}\right]$, chloride $\left[\mathrm{Cl}^{-}\right]$, and sulphate $\left.\left[\mathrm{SO}_{4}^{2-}\right]\right)$. They were analyzed based on the JIS K 0102-2016. As to sediment quality, WC (= [water weight]/[water weight + solids weight]; solids weight determined by drying at $105^{\circ} \mathrm{C}$ ) and IL (weight decrease after ignition at $450^{\circ} \mathrm{C}$ ) of sediment samples were used for the analysis. They were measured based on the Sediment Survey Methods [22].

The data on water and sediment quality reported by the National Institute for Environmental Studies (NIES) [23] were also used to check whether or not similar tendencies to the KRO database could be observed. Water samples were taken using a column sampler $(0-2 \mathrm{~m})$ at 10 sites and sediment samples with a gravity-type core sampler at 3 sites and analyzed with similar methods to KRO. The latter samples were sliced into ten subsamples of $0-1,1-2,2-3.5$, $3.5-5,5-7,7-9,9-11,11-13,13-15$, and 15-17 cm depth. In the NIES database, monthly concentrations of $\mathrm{Na}^{+}, \mathrm{K}^{+}$, $\mathrm{Mg}^{2+}$ and $\mathrm{Ca}^{2+}$ for 1980-2013 were presented (e.g., Supplementary Fig. 1 for St. 1) [23] and the correlations with $\mathrm{KRO}$ data were high (e.g., $0.85^{* *}$ for $\mathrm{Na}^{+}$at St. 1 ), indicating that the decadal change tendency in major cations was represented by KRO data. In addition, the monthly data on sediment WC ratio (= solids weight/water weight), IL and specific density from Feb 1983 to Apr 1990 were reported [23] and the values of WC averaged for $0-11 \mathrm{~cm}$ at the months when KRO sediment samples were taken were calculated using the WC ratios and specific densities at the respective depths. Rather highly scattered changes in WC by KRO as shown below in Fig. 4a were probably due to the fluctuations in sediment sampling depth. But, a high correlation between WC by KRO and that by NIES $\left(r=0.75^{*}\right.$ in Supplementary Fig. 2) at the same months indicated that the sediment data taken by KRO could approximately describe the long-term change in sediment WC despite the grab-sampling. The systematic differences in WC values between them were probably due to the sampling depths and/or sample handling, but the details were uncertain.

Meteorological information (e.g., precipitation) at Tsuchiura and Tateno (Fig. 1) was also used for analysis [24].

\subsection{Experiments}

Two types of experiments were conducted to investigate the changes in sediment WC (WC Experiment, hereafter) and suspended solids (SS) in overlying waters (SS Experiment) after a complete mixing with overlying waters of different salt concentrations. The surface sediment samples of about $10 \mathrm{dm}^{3}$ up to $10-\mathrm{cm}$ depth were taken at St. 1 (Jan. 4 \& Apr. 6, 2019) and St. 4 (Feb. 2, 2019) in order to compare with the results by KRO monitoring, using a bottom grab sampler (Ekman-Birge type), together with water sampling at $0.5 \mathrm{~m}$ below the water surface for analyzing major cations and anions. Immediately after sampling, sediment samples were mixed in the laboratory. Sediment WC, IL and bulk/apparent density (Table 1), and ionic concentrations of interstitial waters for the original sediment samples (Exp. St.1-Jan, St. 4-Feb and St. 1-Apr) were determined in triplicate. IL was measured after burning in a muffle furnace $\left(450^{\circ} \mathrm{C}\right.$ for $\left.120 \mathrm{~min}\right)$. Interstitial waters were obtained with cooled centrifuge $(10,000 \mathrm{rpm}$ for $1 \mathrm{~h})$.

For the WC Experiment, sediment subsamples of $55.0 \mathrm{ml}$ $\left(\mathrm{V}_{\mathrm{s} 0}\right)$ were then put into $100-\mathrm{ml}$ glass tubes with volume scale for WC Experiment (Fig. 2a). Milli-Q water was added for a total volume of $100 \mathrm{ml}$. We prepared 27 tubes for the sediment samples taken on Jan. 4, 2019 (Exp. St. 1-Jan),

Table 1 Water content, ignition loss, bulk density and apparent density of the sediment samples for WC and SS experiments. Average of tree samples

\begin{tabular}{llrll}
\hline & WC (\%) & IL (\%) & $\begin{array}{l}\text { Bulk density } \\
\left(\mathrm{g} \text {-dry } \mathrm{cm}^{-3}\right)\end{array}$ & $\begin{array}{l}\text { Apparent } \\
\text { density }(\mathrm{g}-w e t \\
\left.\mathrm{cm}^{-3}\right)\end{array}$ \\
\hline Exp. St. 1-Jan & 86.1 & 12.5 & 0.151 & 1.09 \\
Exp. St. 4-Feb & 77.6 & 7.4 & 0.268 & 1.19 \\
Exp. St. 1-Apr & 85.6 & 10.5 & 0.158 & 1.09 \\
\hline
\end{tabular}




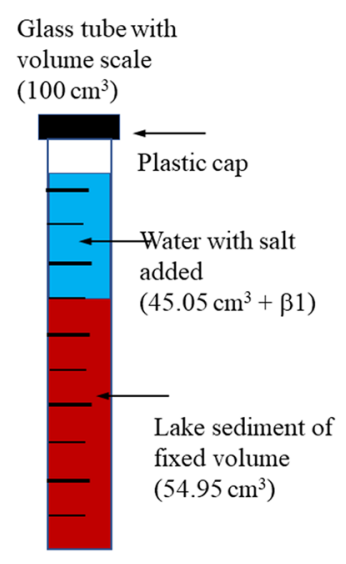

(a) Experiment for sediment water content change (WC Experiment)

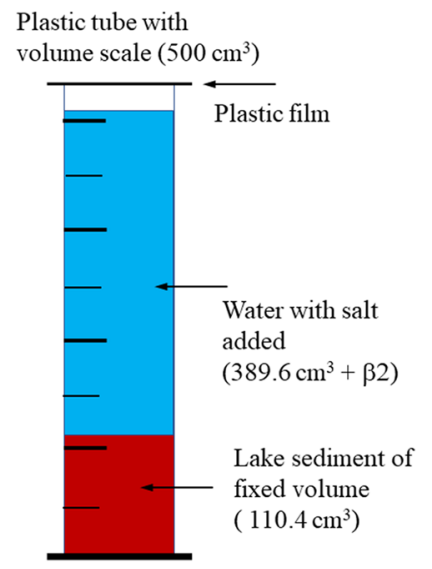

(b) Experiment for suspended sediment concentration change (SS Experiment)

Fig. 2 Experimental settings a WC Experiment: measuring the changes in sediment water content (WC); b SS Experiment: measuring the changes in SS in water. $\beta 1$ and $\beta 2$ were the definite volumes of salt waters to set the salt concentrations in the tubes (see Table 2)

27 tubes for Feb. 2, 2019 (Exp. St. 4-Feb), and 30 tubes for Apr. 6, 2019 (Exp. St. 1-Apr). Definite volumes of salts solutions were added (Table 2; i.e., nonuplicate samples in Exp. St. 1-Jan and St. 4-Feb, and sextuplicate samples in Exp. St. 1-Apr) and then mixed completely. 100-ml glass tubes were chosen considering the data precision and repeatability. The boundary between sediment and overlying water was rather clear one day after mixing, and gradually

descended. At intervals of a few days, the volumes of sediments $\left(V_{s t}\right)$ at the day of $t$ were measured using the scale and then sediment WC $\left(W_{C_{s t}}\right)$ was calculated as follows:

$\mathrm{WC}_{\mathrm{st}}=\left[\mathrm{W}_{\mathrm{w} 0}+\left(\mathrm{V}_{\mathrm{st}}-\mathrm{V}_{\mathrm{s} 0}\right) \times \rho_{\mathrm{w}}\right] /\left[\mathrm{W}_{\mathrm{w} 0}+\mathrm{W}_{\mathrm{s} 0}+\left(\mathrm{V}_{\mathrm{st}}-\mathrm{V}_{\mathrm{s} 0}\right) \times \rho_{\mathrm{w}}\right]$

where, $W_{\text {wo }}$ is water weight in initial sediment subsample of $55.0 \mathrm{ml}, \mathrm{W}_{\mathrm{s} 0}$ is solids weight in it, and $\rho_{\mathrm{w}}$ is specific density of water $\left(=1 \mathrm{~g} \mathrm{~cm}^{-3}\right)$. At several times in Exp. St.1-Jan and Exp. St. 4-Feb, overlying water was taken out from the glass tube using siphon in triplicate. Then, remained sediment subsamples were dried at $105^{\circ} \mathrm{C}$ and water $\left(\mathrm{W}_{\mathrm{w}}\right) /$ solids $\left(W_{s}\right)$ weights were determined. Sediment $W C\left(W C_{s t}{ }^{\prime}\right)$ was calculated as follows and compared with $W C_{s t}$ of the same sample.

$W C_{s t}^{\prime}=W_{w} /\left(W_{w}+W_{s}\right)$

At the end of these experiments (around two weeks), the ionic concentrations of the overlying waters in the three tubes were determined by ion chromatography (DIONEX ICS-2000, Thermo Fisher Scientific Inc., Waltham, MA, USA).

In SS Experiment, 110.4-ml sediment subsamples (Exp. St. 1-Jan and St.4-Feb) were put into 500-ml plastic tubes (Fig. 2b), and Milli-Q water was added for a total volume of $500 \mathrm{ml}$. We prepared 9 tubes for Exp. St. 1-Jan and Exp. St. 4-Feb, respectively. Definite volumes of $\mathrm{NaCl}$ solutions were added to the tubes (Table 2; i.e., triplicate samples in both experiments) and then mixed completely. At intervals

Table 2 Experimental setting of added volumes of salt solutions

\begin{tabular}{|c|c|c|c|c|c|c|}
\hline & No. 1 & No. 2 & No. 3 & No. 4 & No. 5 & No. 6 \\
\hline \multicolumn{7}{|c|}{ (a) WC Experiment } \\
\hline Exp. St. 1-Jan & $\begin{array}{l}\mathrm{NaCl} 1 \mathrm{~cm}^{3} \\
(3.3 \mathrm{mg}) \\
{\left[33.2 \mathrm{mg} \mathrm{dm}^{-3}\right]}\end{array}$ & $\begin{array}{l}\mathrm{NaCl} 2 \mathrm{~cm}^{3} \\
(6.6 \mathrm{mg}) \\
{\left[65.8 \mathrm{mg} \mathrm{dm}^{-3}\right]}\end{array}$ & $\begin{array}{l}\mathrm{NaCl} 4 \mathrm{~cm}^{3} \\
(13.2 \mathrm{mg}) \\
{\left[129 \mathrm{mg} \mathrm{dm}^{-3}\right]}\end{array}$ & & & \\
\hline Exp. St. 4-Feb & $\begin{array}{l}\mathrm{NaCl} 0.5 \mathrm{~cm}^{3} \\
(1.7 \mathrm{mg}) \\
{\left[17.2 \mathrm{mg} \mathrm{dm}^{-3}\right]}\end{array}$ & $\begin{array}{l}\mathrm{NaCl} 1 \mathrm{~cm}^{3} \\
(3.3 \mathrm{mg}) \\
{\left[33.9 \mathrm{mg} \mathrm{dm}^{-3}\right]}\end{array}$ & $\begin{array}{l}\mathrm{NaCl} 2 \mathrm{~cm}^{3} \\
(6.6 \mathrm{mg}) \\
{\left[66.9 \mathrm{mg} \mathrm{dm}^{-3}\right]}\end{array}$ & & & \\
\hline \multirow[t]{2}{*}{ Exp. St. 1-Apr } & Nothing & $\begin{array}{l}\mathrm{NaCl} 0.5 \mathrm{~cm}^{3} \\
(1.7 \mathrm{mg}) \\
{\left[16.7 \mathrm{mg} \mathrm{dm}^{-3}\right]}\end{array}$ & $\begin{array}{l}\mathrm{NaCl} 1 \mathrm{~cm}^{3} \\
(3.3 \mathrm{mg}) \\
{\left[33.3 \mathrm{mg} \mathrm{dm}^{-3}\right]}\end{array}$ & $\begin{array}{l}\mathrm{NaCl} 2 \mathrm{~cm}^{3} \\
(6.6 \mathrm{mg}) \\
{\left[66.0 \mathrm{mg} \mathrm{dm}^{-3}\right]}\end{array}$ & $\begin{array}{l}\mathrm{MgCl}_{2} 1 \mathrm{~cm}^{3} \\
(5.4 \mathrm{mg}) \\
{\left[54.6 \mathrm{mg} \mathrm{dm}{ }^{-3}\right]}\end{array}$ & $\begin{array}{l}\mathrm{CaCl}_{2} 1 \mathrm{~cm}^{3} \\
(6.3 \mathrm{mg}) \\
{\left[63.7 \mathrm{mg} \mathrm{dm}^{-3}\right]}\end{array}$ \\
\hline & & No. 1 & & No. 2 & & No. 3 \\
\hline \multicolumn{7}{|c|}{ (b) SS Experiment } \\
\hline Exp. St. 1-Jan & & $\begin{array}{l}\mathrm{NaCl} 5 \mathrm{~cm}^{3} \\
(16.5 \mathrm{mg}) \\
{\left[33.3 \mathrm{mg} \mathrm{dm}^{-3}\right]}\end{array}$ & & $\begin{array}{l}\mathrm{NaCl} 10 \mathrm{~cm}^{3} \\
(33 \mathrm{mg}) \\
{\left[66.5 \mathrm{mg} \mathrm{dm}^{-3}\right]}\end{array}$ & & $\begin{array}{l}\mathrm{NaCl} 20 \mathrm{~cm}^{3} \\
(66 \mathrm{mg}) \\
{\left[133 \mathrm{mg} \mathrm{dm}{ }^{-3}\right]}\end{array}$ \\
\hline Exp. St. 4-Feb & & $\begin{array}{l}\mathrm{NaCl} 2.5 \mathrm{~cm}^{3} \\
(8.3 \mathrm{mg}) \\
{\left[16.8 \mathrm{mg} \mathrm{dm}^{-3}\right]}\end{array}$ & & $\begin{array}{l}\mathrm{NaCl} 5 \mathrm{~cm}^{3} \\
(16.5 \mathrm{mg}) \\
{\left[33.2 \mathrm{mg} \mathrm{dm}^{-3}\right]}\end{array}$ & & $\begin{array}{l}\mathrm{NaCl} 10 \mathrm{~cm}^{3} \\
(33 \mathrm{mg}) \\
{\left[65.7 \mathrm{mg} \mathrm{dm}{ }^{-3}\right]}\end{array}$ \\
\hline
\end{tabular}

Concentrations of salt solutions: $\mathrm{NaCl}: 3.3 \mathrm{~g} \mathrm{dm}^{-3}, \mathrm{MgCl}_{2}: 5.37 \mathrm{~g} \mathrm{dm}^{-3}, \mathrm{CaCl}_{2}: 6.26 \mathrm{~g} \mathrm{dm}^{-3}$. ( ): added salt amount. [ ]: expected increased salt concentration 
of around one week, 100-ml subsamples were taken from nearly the middle of the overlying waters in each plastic tube using a 5-ml micropipette. Subsequently, SS on the filter (Whatman GF/B) and the ionic concentrations for the filtrate were determined.

\subsection{Statistical methods}

Statistical analyses were used to determine the correlation, differences between the means (t-test) and the regression analysis for significance at the level of $p=0.05\left(^{*}\right)$ or $\left.p=0.01{ }^{* *}\right)$ (Excel Statistics for 2016: BellCurve Social Survey Research Information Co., Tokyo and OriginPro 2017J: OriginLab. Corp., Northampton, USA).

\section{Results}

\subsection{Long-term changes in water and sediment qualities}

The gradual decreases of $\mathrm{Na}^{+}, \mathrm{Cl}^{-}$and $\mathrm{SO}_{4}^{2-}$ were observed from 1980 to the first half of the 1990s (Fig. 3a). The peaks of $\mathrm{Na}^{+}$and $\mathrm{Cl}^{-}$occurred during the second half of the 1990s, followed by a decreasing trend until present. In the case of other ions, the trends after 1990 were rather unclear. Comparing $\mathrm{Cl}^{-}$changes in Fig. 3a, b, monthly variations seemed moderate and probably due to precipitation changes. Almost all ions were slightly correlated $\left(\mathrm{Ca}^{2+}\right.$ vs $\mathrm{K}^{+}: \mathrm{r}=0.07, \mathrm{Ca}^{2+}$ vs $\mathrm{SO}_{4}^{2-}: \mathrm{r}=0.13^{*}$, other combinations: $r>0.17^{* *}$ at St. 1). Concentrations of the same ion were correlated at the five stations (e.g., $\mathrm{Cl}^{-1}$ in Fig. 3b; correlation coefficients $r \geq 0.87^{* *}$ ) whereas the average values (shown in the caption of this figure) increased toward the outlet of the lake. These tendencies were also confirmed for the ion data obtained by NIES. Very similar cation trends were observed at St. 1 in the NIES database (Supplementary Fig. 1).

The changes in sediment WC and IL at St. 1, 2, 3 and 4 are shown in Fig. $4 a, b$, respectively. The values at St. 5 are not shown in these figures because quite lower WC and IL were observed at this station (Supplementary Table 2). These low WC and IL values were due to the high percentage of sand in the sediment. A gradual decrease of sediment WC was observed from 1980-1990. Levels then increased until the latter half of the 1990s, and have been lower with large fluctuation since the latter half of the 2000s. The changes in WC at the four stations were significantly correlated $\left(r \geq 0.62^{* *}\right)$, as were the changes in IL $\left(r \geq 0.46^{* *}\right)$.

\subsection{Relationship between mineral concentration and sediment WC}

Significant correlations were observed between sediment WC and mineral ion concentrations $\left(\mathrm{Cl}^{-}: \mathrm{r}=0.47^{* *} ; \mathrm{Na}^{+}\right.$: $\left.\mathrm{r}=0.70^{* *} ; \mathrm{K}^{+}: \mathrm{r}=0.53^{* *} ; \mathrm{Mg}^{2+}: \mathrm{r}=0.50^{* *} ; \mathrm{SO}_{4}^{2-}: \mathrm{r}=0.55^{* *}\right)$, except for $\mathrm{Ca}^{2+}(r=0.12)$ at St. 1. Furthermore, the correlations with time lag were stronger as shown in Supplementary Table 3 (1) (e.g., previous 3-y average in Fig. 5 vs compared with no delay in Supplementary Fig. 3). Similar significant correlations with sediment WC were also observed at other stations (Supplementary Table 3 (2)). Similar significant correlations were also observed in
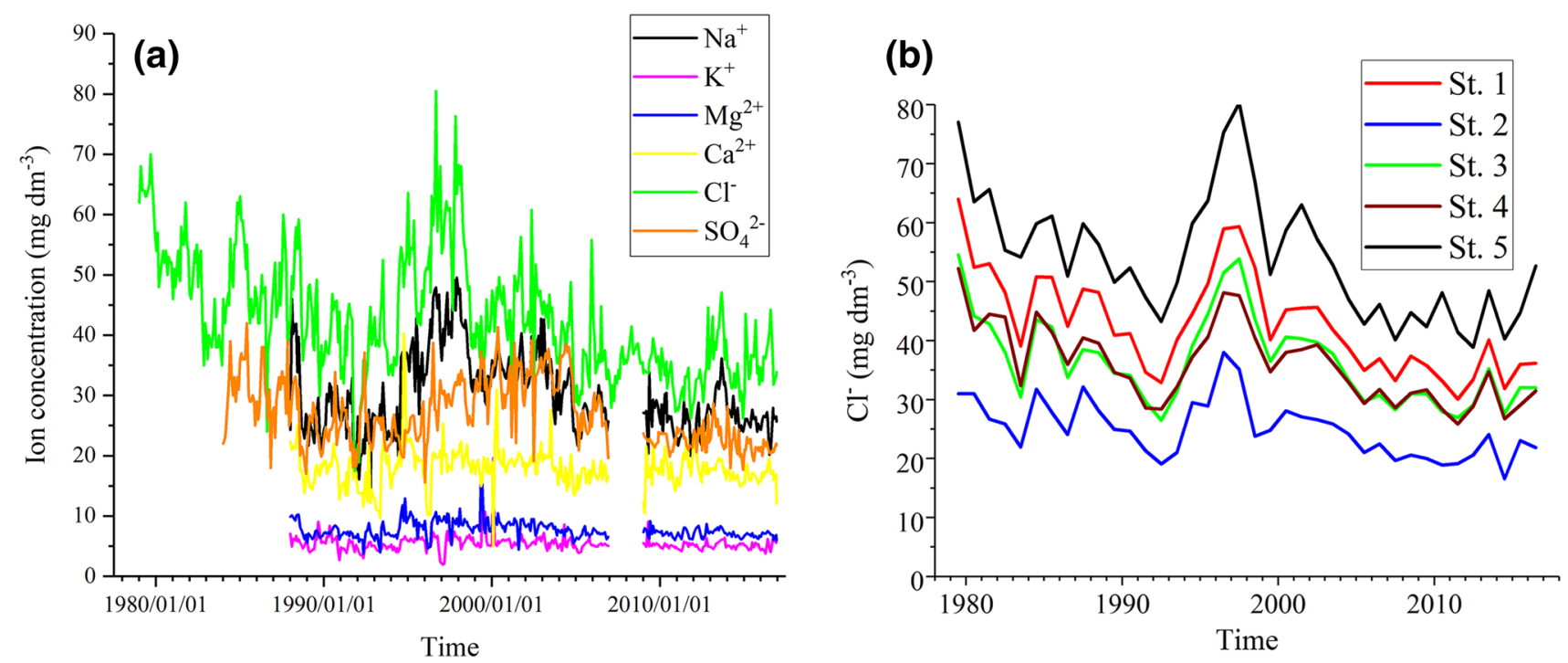

Fig. 3 Decadal changes in the concentrations of: a major cations and anions at St. $1 ; \mathbf{b}$ yearly averaged $\mathrm{Cl}^{-}$at 5 stations. St. 1: $42.9 \pm 8.4 \mathrm{mg}$ $\mathrm{dm}^{-3}$, St. 2: $25.0 \pm 4.8 \mathrm{mg} \mathrm{dm}^{-3}$, St. 3: $36.4 \pm 7.4 \mathrm{mg} \mathrm{dm}^{-3}$, St. $4: 35.9 \pm 6.6 \mathrm{mg} \mathrm{dm}^{-3}$, St. 5: $54.0 \pm 10.5 \mathrm{mg} \mathrm{dm}^{-3}$ (average \pm standard deviation) 

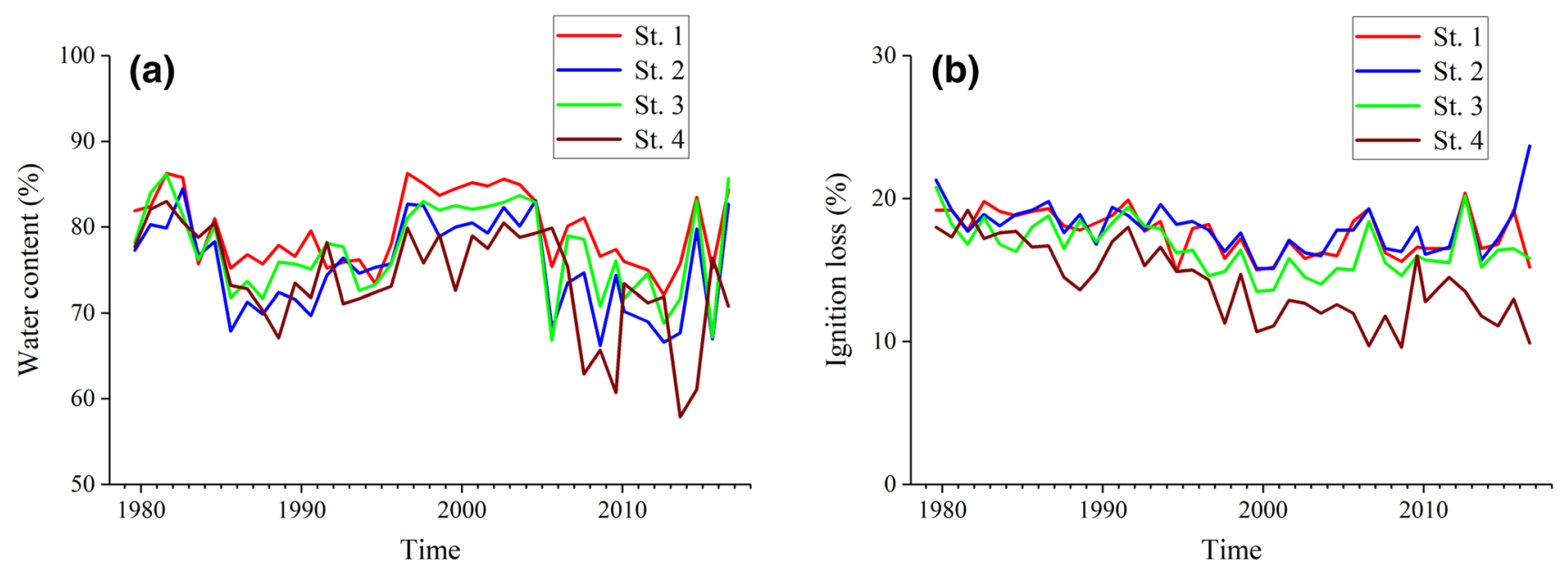

Fig. 4 Yearly changes in sediment at 4 stations: a water content; $\mathbf{b}$ ignition loss

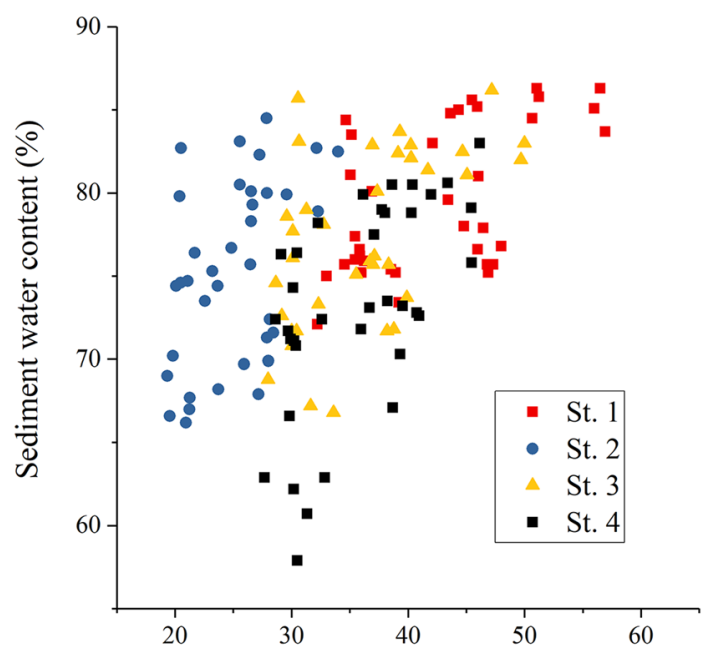

$\mathrm{Cl}^{-}$in water $\left(\mathrm{mg} \mathrm{dm}^{-3}\right)$ averaged previous 3 years

Fig. 5 Relationship between $\mathrm{Cl}^{-}$in water averaged for the previous 3 years and sediment water content at 4 stations: $r=0.55^{* *}$ at St. 1 ; $r=0.46^{* *}$ at St. $2 ; r=0.53^{* *}$ at St. $3 ; r=0.59^{* *}$ at St. 4

NIES ion data $\left(r=0.72^{* *}\right.$ for $\mathrm{Na}^{+} ; r=0.46^{*}$ for $\mathrm{K}^{+} ; \mathrm{r}=0.67^{* *}$ for $\mathrm{Mg}^{2+} ; \mathrm{r}=0.75^{* *}$ for $\mathrm{Ca}^{2+}$ at St. 1; e.g., Supplementary Table 3 (3), Supplementary Fig. 4).

\subsection{Experimental results}

First, volume method and standard analytical method for determining sediment WC were compared (Supplementary Fig. 5 (1), (2)). The results showed good agreement, indicating that the changes in WC estimated by the volume method were reliable.

When $\mathrm{NaCl}$ was added, $\mathrm{Na}^{+}$usually showed smaller concentrations than expected after complete mixing of the sediments with the overlying waters, whereas other

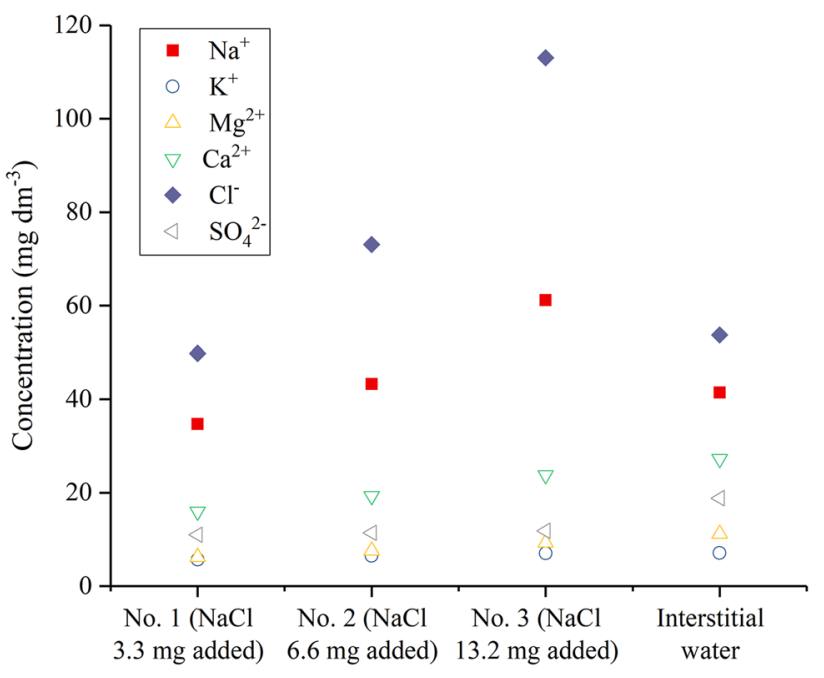

Fig. 6 Concentrations of major cations and anions after addition of $\mathrm{NaCl}$ solutions in WC Experiment, Exp. St. 1-Jan. Expected increased $\mathrm{NaCl}$ concentration; No. 1: $33.2 \mathrm{mg} \mathrm{l}^{-1}$, No. 2: $65.8 \mathrm{mg} \mathrm{l}^{-1}$, No. 3: 129 $\mathrm{mg} \mathrm{I}^{-1}$

cations were higher than expected (Table 2, Fig. 6, Supplementary Fig. 6 (1) \& (2)). This basically indicates that $\mathrm{Na}^{+}$is incorporated into sediments, while other cations are dissolved from them, suggesting ion exchange in or on sediments.

In the WC Experiments, the sediment WC decreased exponential during the experimental periods as shown in Fig. 7a-c. Significantly lower values of WC were observed in lower ionic conditions, particularly in the early periods of the experiments. The final WC did not reach the original WC level during the periods, indicating that compaction of the sediments takes time (more than 2 weeks). The addition of $\mathrm{MgCl}_{2}$ and $\mathrm{CaCl}_{2}$ brought about similar 

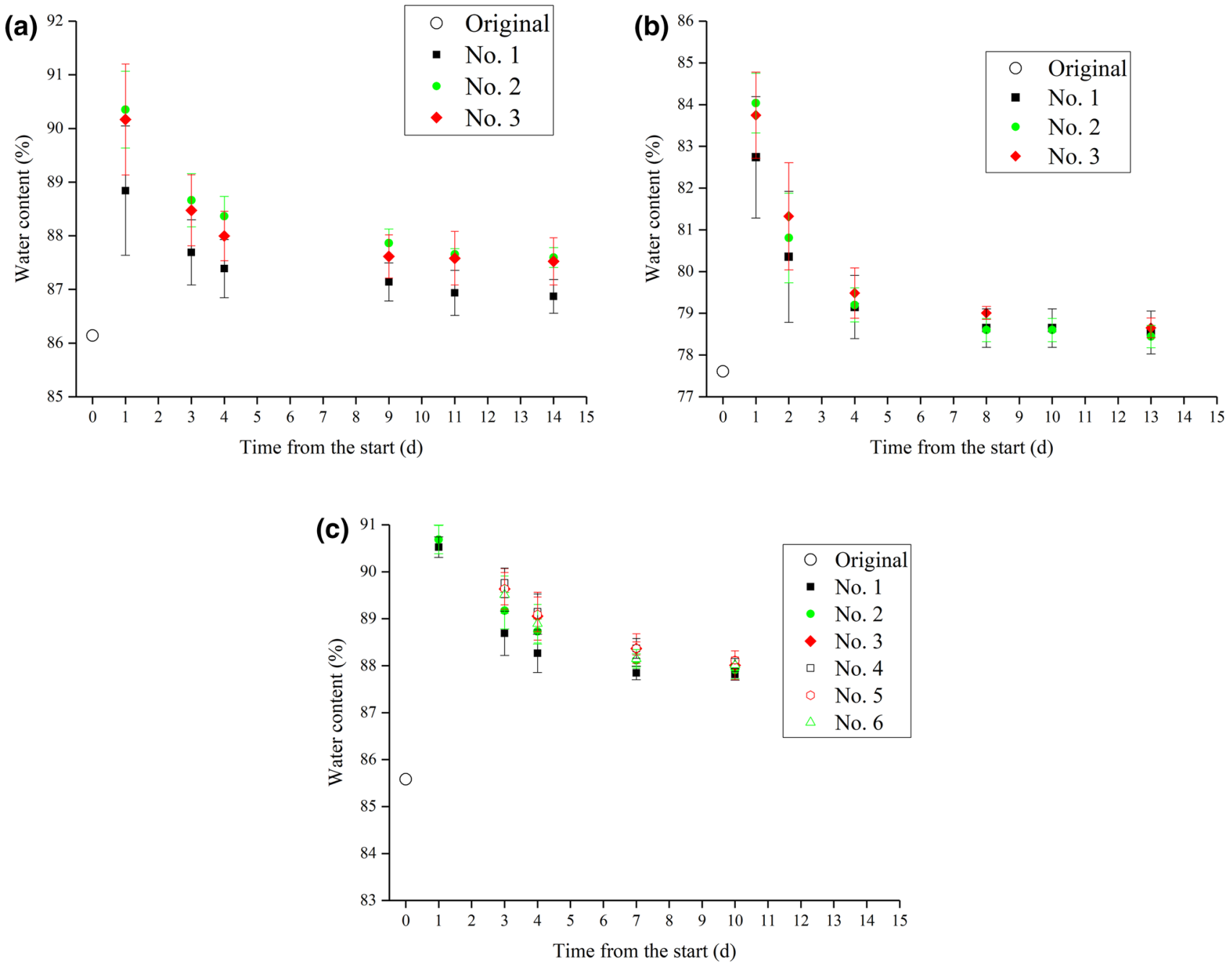

Fig. 7 Changes in sediment water content in WC Experiment. a Exp. St.1-Jan, Original: original sediment sample, expected increased $\mathrm{NaCl}$ concentration; No. 1: $33.2 \mathrm{mg} \mathrm{I}^{-1}$, No. 2: $65.8 \mathrm{mg}$ $\mathrm{I}^{-1}$, No. 3: $129 \mathrm{mg} \mathrm{I}^{-1}$. b Exp. St. 4-Feb, Original: original sediment sample, expected increased $\mathrm{NaCl}$ concentration; No. 1: $17.2 \mathrm{mg}$

influences as $\mathrm{NaCl}$ addition on WC. In the SS Experiments, significantly lower SS concentrations in overlying waters were observed in higher ionic conditions (Fig. 8 and Supplementary Fig. 7).

\subsection{Influence of meteorological conditions on mineral concentrations}

Correlation analysis between meteorological parameters and ion concentrations in the lake showed that only precipitation significantly affected these concentrations. For example, yearly precipitation level was significantly negatively correlated with $\mathrm{Na}^{+}\left(r=-0.51^{* *}\right), \mathrm{Mg}^{2+}\left(r=-0.59^{* *}\right)$, $\mathrm{Ca}^{2+}\left(\mathrm{r}=-0.49^{*}\right)$, and $\mathrm{Cl}^{-}\left(\mathrm{r}=-0.50^{* *}\right)$ (insignificant: $r=-0.29$ for $\mathrm{K}^{+}$and $\mathrm{r}=-0.28$ for $\left.\mathrm{SO}_{4}^{2-}\right)$. Correlations
$\mathrm{I}^{-1}$, No. $233.9 \mathrm{mg} \mathrm{I} \mathrm{I}^{-1}$, No. 3: $66.9 \mathrm{mg} \mathrm{I^{-1 }}$. c Exp. St. 1-Apr, Original: original sediment sample, expected increased $\mathrm{NaCl}$ concentration; No. 1: nothing, No. $216.7 \mathrm{mg} \mathrm{I}^{-1}$, No. 3: $33.3 \mathrm{mg} \mathrm{I}^{-1}$, No. $4: 66.0 \mathrm{mg}$ $\mathrm{I}^{-1}$ expected increased $\mathrm{MgCl}_{2}$ concentration; No. 5: $54.6 \mathrm{mg} \mathrm{I}^{-1}$, expected increased $\mathrm{CaCl}_{2}$ concentration; No. 6: $63.7 \mathrm{mg} \mathrm{I}^{-1}$

with average precipitation over longer time spans were stronger (e.g., correlation of $\mathrm{Cl}^{-}$with previous 2-y average of precipitation $r=-0.81^{* *}$; with previous 3 -y average precipitation $r=-0.84^{* *}$ as shown in Fig. 9; with previous 4-y average precipitation $r=-0.83^{* *}$ ).

\section{Discussion}

\subsection{Relationship between salinity and water content in sediments}

Many factors could change the WC of lake sediment. First, bioturbation of sediment through movement of benthic animals, e.g., bivalves, insects, shrimps, fish, 


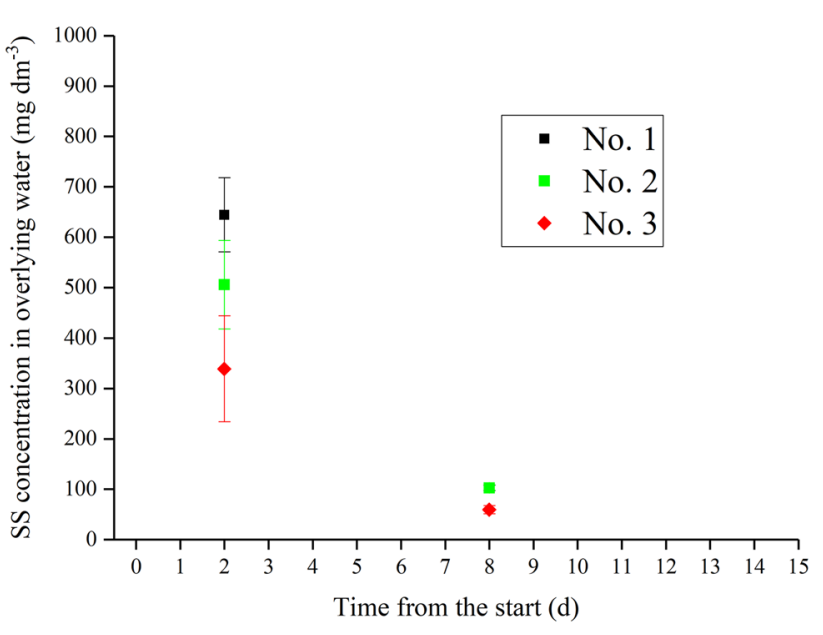

Fig. 8 Changes in SS concentrations in SS Experiment, Exp. St.1Jan. Expected increased $\mathrm{NaCl}$ concentration; No. 1: $33.3 \mathrm{mg} \mathrm{I}^{-1}$, No. 2: $66.5 \mathrm{mg} \mathrm{l}^{-1}$, No. 3: $133 \mathrm{mg} \mathrm{I}^{-1}$

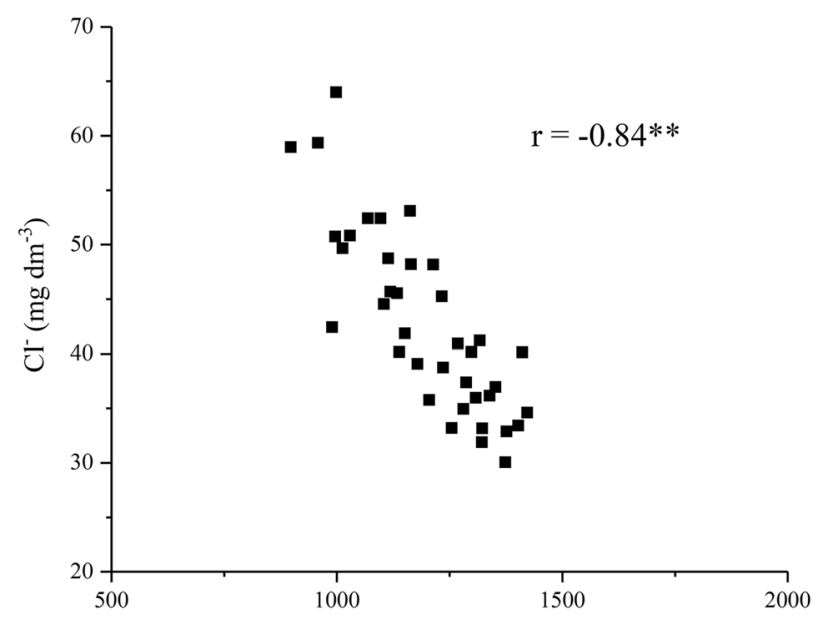

Precipitation at Tsuchiura averaged for previous 3 years $\left(\mathrm{mm} \mathrm{y}^{-1}\right)$

Fig. 9 Relationship between precipitation amount at Tsuchiura averaged for the previous 3 years and $\mathrm{Cl}^{-}$in water at St. 1

increases sediment WC $[25,26]$. In Lake Kasumigaura, the density of chironomid larvae, the most dominant benthic organism, had peaked in 1980, and gradually declined thereafter [27]; thus, the peak of WC in the latter half of 1990s could not be explained by the biomass change in this organism. As to benthic fish and shrimp, there was a shift from native species belong to Cryrindae (e.g., crucian carp), Gobiidae (e.g., goby), Macrobrachium (e.g., freshwater prawn), etc. to non-native channel catfish around 2000, which happened due to food competition rather than predation [28]. This shift, however, did not correspond to the changes in sediment WC or water mineral concentrations. Second, the frequency of sediment resuspension might affect sediment WC.
In Lake Kasumigaura, sediment resuspension is principally caused by wind wave [18]. The magnitude of wind wave is determined by wind fetch and velocity, but there were not clear decadal changes in wind velocity (e.g., yearly maximum wind velocity, number of days when daily maximum wind velocity was larger than $10 \mathrm{~m} \mathrm{~s}^{-1}$; [3]). Third, the sediment WC and porosity monotonously decreased from the surface to the depth of more than $40 \mathrm{~cm}$ [20], indicating relatively stable sedimentation processes. Thus, we suspected the relationship between salinity and sediment WC.

The experimental results on the relationships between $\mathrm{Cl}^{-}$concentration in lake water and sediment WC were added to those relationships obtained in the field (Fig. 10). The tendency for WC to increase with $\mathrm{Cl}^{-}$concentration (positive relation between WC and $\mathrm{Cl}^{-}$) was found in both field observations and experimental results, but the WC ranges and slopes of the relationship ( $\mathrm{Cl}^{-}$vs. WC) were different. In addition, the relationship observed in the experiment using St. 4 sediments was less clear. The difference in WC ranges was probably due to the difference in mixing and/or sedimentation conditions (e.g., depth of sediment layer, mixing strength/duration, ion content and concentration, time scale of compaction, etc.) also could affect the results, but it was important to get a similar tendency with salinity.

There have been many studies on the relationship between swelling rate of clay and salt concentration in clay-water systems. Shiraki [10] reported that swelling rates of one type of clay (Ohata-Kibushi) increased with $\mathrm{NaCl}$ concentration up to $0.1 \mathrm{M}$ (from $8 \%$ swelling at $0 \mathrm{M}$ to $18 \%$ swelling at $0.1 \mathrm{M}$ ) using the apparatus for measuring linear imbibitional swelling expansion (clay sample separated by porous non-expansion material from solution with definite salt concentration; swelling rate determined after the steady state), but indicated a negative relation for Honyama-Kibushi clay up to $0.1 \mathrm{M}$ (from $16 \%$ swelling at $0 \mathrm{M}$ to $10 \%$ swelling at $0.1 \mathrm{M}$ ). In addition, he showed that $\mathrm{Na}^{+}$has higher swelling rates than $\mathrm{Ca}^{2+}, \mathrm{K}^{+}, \mathrm{Mg}^{2+}$ and $\mathrm{NH}_{4}{ }^{+}$ and that the relationships were influenced by the organic matter contained in the clay samples.

Avnimelech et al. [29] reported that sediment bulk density was inversely related to the organic matter concentration (Table 1 for our sediments). They considered the possibility that the organic matter is highly hydrated and that the structure of mineral bottom sediments may be conceptualized as mineral particles spaced apart by organic micelles. Particularly near the interface between water and sediment, the hydrated organic particles have an almost buoyancy and their settling takes time. It could be expected that salinity increase reduces the density difference between water and the hydrated particles and then produces sediments of low compaction. 

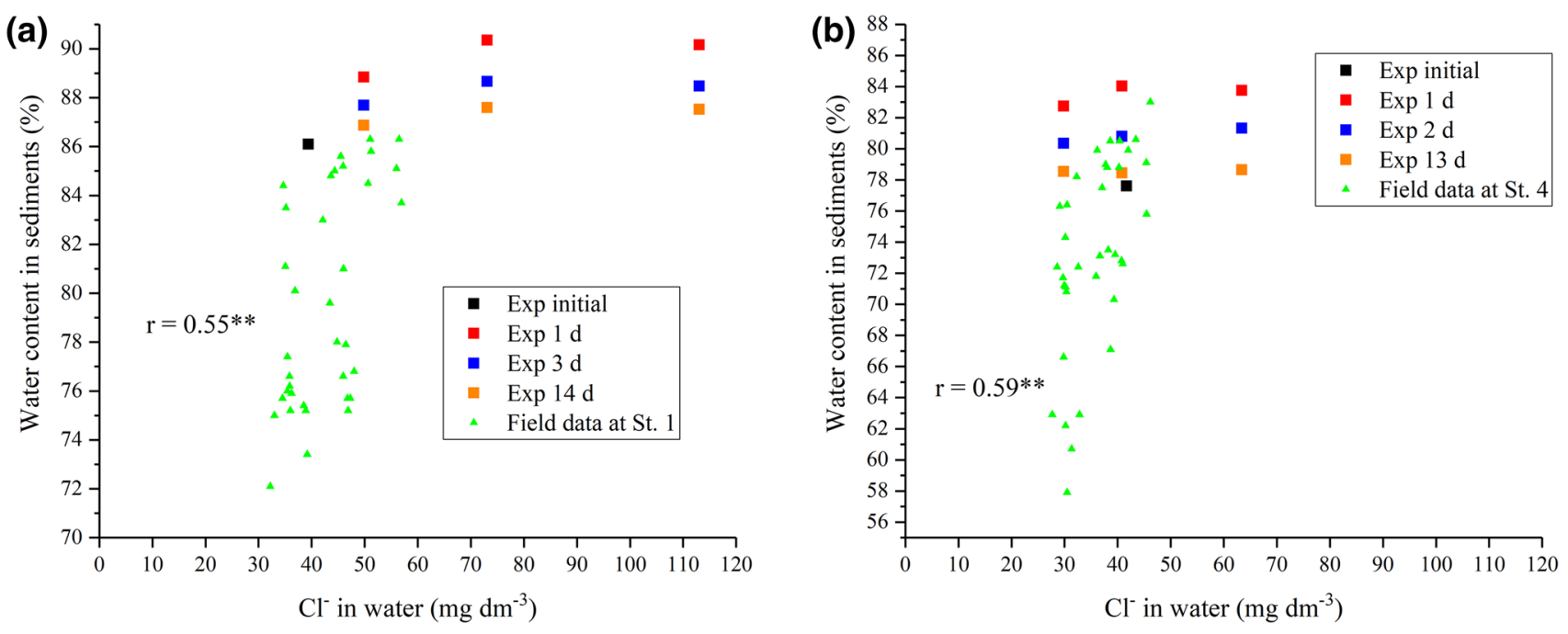

Fig. 10 Relationship between $\mathrm{Cl}^{-}$in water (experimental results and field observation averaged for previous 3 years) and sediment water content: a St. 1; b St. 4. Symbols are explained in text

Zhu et al. [13] investigated the effects of particle concentration and salinity conditions on the flocculation and settling characteristics of sediment suspension using the sediment materials taken in the Yellow River. Two sets of experiments (low- and high-concentration sediment suspensions) were performed; the primary particle concentrations were $1-12 \mathrm{gl}^{-1}$ in the low-concentration test and $200-350 \mathrm{~g} \mathrm{dm}^{-3}$ in the high-concentration test. Because clear water-turbid water (sediment) interfaces were seen in the latter test, our WC Experiment (primary particle concentration: $83 \mathrm{~g} \mathrm{dm}^{-3}$ for Exp. St. 1-Jan, $147 \mathrm{~g} \mathrm{dm}^{-3}$ for Exp. St. 4-Feb, $87 \mathrm{~g} \mathrm{dm}^{-3}$ for Exp. St. 1-Apr) corresponded to the latter. In this high-concentration test, increasing salinity (0.005- $0.1 \mathrm{M}$ of $\left.\mathrm{Al}\left(\mathrm{NO}_{3}\right)_{3}\right)$ or valence of cations $(0.005 \mathrm{M}$ of $\mathrm{NaCl}, \mathrm{CaCl}_{2}$ and $\left.\mathrm{Al}\left(\mathrm{NO}_{3}\right)_{3}\right)$ added to the suspension made the descending rate of the interface slow down, indicating similar characteristics to the results of our WC Experiment. They considered that these characteristics were due to the following mechanism. When salinity concentration increases, the double-layer repulsive forces between the two colliding primary particles and/or flocs will decrease, further leading to an increasing comprehensive shortrange force between two particles/flocs. As a result, the strength of the space-filling network structure becomes greater. Therefore, the free water inside the network structure becomes more difficult to squeeze and water discharge needs to take a longer time.

In contrast, Yilmaz and Marschalko [11] reported that distilled water showed the highest swell percentage and pressure of bentonite taken near Resadiye (the Black Sea region of Turkey) compared to seven other natural waters (fresh to saline: salinity $0.15-35$ ) based on the free swell test, indicating a nearly negative relationship. Bharat and
Das [12] measured equilibrium sediment volumes (ESV: expressed in $\mathrm{cm}^{3} \mathrm{~g}^{-1}$ ) of several types of bentonites and natural clay samples and showed that ESVs decreased with salt concentrations in the solutions $\left(\mathrm{NaCl}\right.$ and $\left.\mathrm{CaCl}_{2}\right)$ in the range from $0.001-2 \mathrm{M}$. In addition, they proposed a simple analytical model relating ESV to different influencing physicochemical parameters using the diffuse double layer theory and confirmed that this model was very useful for understanding the influencing parameters on bentonite behavior.

In the range above $0.1 \mathrm{M}$ of salt solution, a negative relationship between salinity and swell percentage was common in above-mentioned references, but below this level (characterizing our lake) the relationship depended on the sediment composition. The sediments of Lake Kasumigaura showed a positive relationship by both field observation and laboratory experiments, but this relationship would be not general in other fields and/or different salt ranges. There is a possibility that complex interactions among free, adsorbed and/or incorporated ions, clay, and organic matter affect the swelling percentages (sediment compaction speed), but the details are unknown. In addition, the difference in the slopes of the relationship between field observation and experimental results as shown in Fig. 10a, b was probably due to the differences in sedimentation conditions (e.g., depth of sediment layer, mixing strength/duration, ion content and concentration), time scale of compaction (a few weeks in the experiment vs. a few years in the field), influence of sediment IL changes, etc. Particularly for the sediments at St. 4, other mechanisms would possibly affect the relationship. By the way, a time lag of a few years was observed in the relationship between mineral concentration in lake 
water and sediment WC. This time-lag happened probably because sufficient time was required to mix substantially the surface sediments (up to $10 \mathrm{~cm}$ ) with lake water in reference to strong wind frequency.

On the other hand, significantly higher SS concentrations in overlying waters observed in lower ionic conditions (SS Experiment) were similar to previous studies. Many studies indicated fast sedimentation of both riverine suspended matter and dissolved constituents during the mixing of river water and seawater [5-8]. In this study, rather small increases in $\mathrm{NaCl}$ concentrations (scores of milligrams per liter) resulted in significantly lower SS concentrations in overlying waters (Fig. 8, Supplementary Fig. 7), confirming the results obtained in coastal freshwater wetlands [9]. In addition, high numbers of bacteria were observed in the sediments of Lake Kasumigaura (e.g., total heterotrophs: around $10^{7}$ cells $\mathrm{g}^{-1}$ in $0-2 \mathrm{~cm}$ sediments near St. 2 [30]). Such organisms included in SS in the experiment would be died by the elevated salt concentration and SS concentration was decreased. However, based on the finding that the direct influence of changes in mineral concentrations on the tripton trend was not of major importance (insignificant correlations between tripton and major ions [3]), we would conclude that the indirect influence through sediment WC change was influential on suspended particle concentrations in Lake Kasumigaura as shown in Introduction [3, 4]. That is, tripton concentration in this lake is mainly governed not by settling process, but by resuspension process.

\subsection{Causes for mineral concentration changes}

The population in the basin increased from the latter half of 1960s to 2000 and became nearly constant after that. Fukushima et al. [30] reported that predominant land use/cover changes were from forest to golf-course in the period of 1979-1990, and from forest to artificial field in the period of 1990-1996 using high quality GIS datasets. In addition, Fang et al. [31] showed that the ISA (Impervious Surface Area) fractions in the basin increased from $19.9 \%$ in 1987 to $23.7 \%$ in 2007 by analyzing Landsat-5 TM images. Considering the exporting $\mathrm{Cl}^{-}$load from the respective land use/cover patterns [32], it could be expected that the gradual increase in $\mathrm{Cl}^{-}$input from the influent rivers happened during the study period (1979-2016). This expected trend did not correspond to the $\mathrm{Cl}^{-}$change in lake water.

The discharge-weighted average of $\mathrm{Cl}^{-}$concentration in the 10 main influent rivers (Fig. 1) was $27.8 \mathrm{mg} \mathrm{dm}^{-3}$ based on the weekly survey for one year [33]. This concentration was almost always lower than $\mathrm{Cl}^{-}$concentrations at Sts. $1,3,4$ and 5 which were not so close to the river mouths (Fig. 3a, b). The $\mathrm{Cl}^{-}$concentrations at Itako (about $6 \mathrm{~km}$ downstream from the outlet of Lake Kasumigaura), Sotonasakaura (about $10 \mathrm{~km}$ downstream) and lkisu (about 14 km downstream) (Supplementary Fig. 8) were higher than those at St. 1-5, but their changes were similar (Fig. 3a, b), indicating more salt input in the downstream area and/ or salty water came from the downstream. In addition, negative correlations between precipitation integrated for previous a few years and salt concentrations were observed (Fig. 9). As shown in Supplementary Fig. 9, the years from 1994-1997 had significantly low annual precipitation, that likely caused the high $\mathrm{Na}^{+}$and $\mathrm{Cl}^{-}$concentrations observed in the lake waters in the latter half of the 1990s. Therefore, we supposed that this high salt event was possibly caused by sea-spray aerosols, evaporation through flowing down, and/or salty water came from the downstream.

The concentration of sea-spray aerosols decreased exponentially from the sea [34], suggesting that the deposition salt flux on the ground changed in a similar manner. As to the evaporation from the lake, Sugita et al. [35] reported that the mean annual rate was $911 \pm 42 \mathrm{~mm}$ $y^{-1}$ for the period of 2008-2012. This rate was nearly the same as the precipitation rates in 1994-1997, indicating no net input of water and gradual increase in net input of salt from the air in the downstream direction. However, the quantitative evaluation of this combined influence (sea-spray aerosol and evaporation) was difficult because many components related to the salt budget have not been measured accurately.

On the other hand, the Hitachitone River gate has been controlled considering the discharge rate at this river and water level for flood and water resource management. Because the raises in salt concentration in the upstream side of the gate were sometimes observed during the period when the gate was closed (data not shown). These raises suggest the intrusion of salty water through the gate and/or surrounding construction structures. During low precipitation years, this kind of intrusions were expected, but the quantitative contribution to the high salt concentrations observed in the lake waters in the latter half of the 1990 s was difficult to measure. Anyway, low precipitation for a few years brought about high salt conditions in lake water. This was a very rare meteorological event, but its influence on lake water quality was quite large.

\section{Conclusions and outlook}

We analyzed long-term changes in the main ions and sediment properties of a shallow eutrophic lake based on 38 years of monitoring data. Significant correlations between main ions in lake water and sediment WC with a time lag of a few years were observed. This relationship 
was confirmed by laboratory experiments which indicated sediment swelling (slowdown of sediment compaction) by adding $\mathrm{NaCl}$ into a water-sediment system. The high mineral concentrations observed in the lake water in the latter half of the 1990s were due to extremely low annual precipitation for a number of years. As shown in Fukushima et al. [3], the change in sediment properties brought about decadal trends in tripton concentration, which could affect many physical, chemical and biological processes in shallow lakes.

This study pointed out close and complicated relationships among meteorological condition, lake water salinity and sediment properties. Thus, climate changes are likely to result in considerable impacts in lake abiotic (water temperature rise, changes in rainfall pattern, storm frequency, and water level, etc.) and biotic systems (changes in biological activity, nutrient cycle, and phenology, invasion of alien species, etc.). Further studies on prediction schemes and management strategies to address such impacts in shallow lakes will be necessary.

Acknowledgements This work was supported in part by Grants-in-Aid for Scientific Research from the Ministry of Education, Culture, Sport, Science and Technology (MEXT), Japan (17H04475 and 17H01850). The data on lake water and sediment quality were provided by Kasumigaura River Office, Kanto Regional Development Bureau, Ministry of Land, Infrastructure, Transport and Tourism (MLIT). Monitoring data on water quality and phytoplankton were also provided by National Institute for Environmental Studies (NIES). The authors would also like to thank four anonymous reviewers and section editor for their valuable comments and suggestions for improving the quality of the manuscript.

\section{Compliances with ethical standards}

Conflict of interest The authors declare that they have no conflict of interest.

\section{References}

1. Philips EJ, Aldridge FJ, Schelske CL, Crisman TL (1995) Relationships between light availability, chlorophyll-a and tripton in a large, shallow subtropical lake. Limnol Oceanogr 40:416-421. https://doi.org/10.4319/lo.1995.40.2.0416

2. Effler SW, Prestigiacomo AR, Matthews DA, Gelda RK, Peng F, Cowen EA, Schweitzer SA (2010) Tripton, trophic state metrics, and near-shore versus pelagic zone responses to external loads in Cayuga Lake, New York, U.S.A. Fund Appl Limnol 178:1-15. https://doi.org/10.1127/1863-9135/2010/0178-0001

3. Fukushima T, Komuro S, Kitamura T, Nagahama Y, Matsushita B (2019) Decadal change in tripton concentration in a shallow lake. SN Appl Sci 1:1637. https://doi.org/10.1007/s4245 2-019-1668-91

4. Otsubo K (1984) Experimental studies on the physical properties of mud and the characteristics of mud transportation. Res Rep Nat Ins Environ Stud (NIES) 42:1-177 (in Japanese with English abstract)
5. Boldrin A, Juracic M, Vitturi LM, Rabitti S, Rampazzo G (1992) Sedimentation of riverborne material in a shallow shelf seaAdige River, Adriatic Sea. Mar Geol 103:473-485. https://doi. org/10.1016/0025-3227(92)90033-e

6. Muller FLL, Tranter M, Balls PW (1994) Distribution and transport of chemical-constituents in the Clyde estuary. Estuar Coast Shelf Sci 39:105-126. https://doi.org/10.1006/ ecss.1994.1052

7. Wolanski E, Huan NN, Dao LT, Nhan NH, Thuy NN (1996) Finesediment dynamics in the Mekong river estuary, Vietnam. Estuar Coast Shelf Sci 43:565-582. https://doi.org/10.1006/ ecss.1996.0088

8. Sholkovitz ER (1976) Flocculation of dissolved organic and inorganic matter during mixing of river water and seawater. Geochim Cosmochim Acta 40:831-845. https://doi. org/10.1016/0016-7037(76)90035-1

9. van Dijk G, Smolders AJP, Loeb R, Bout A, Roelofs JGM, Lamers LPM (2015) Salinization of coastal freshwater wetlands; effects of constant versus fluctuating salinity on sediment biogeochemistry. Biogeochemistry 126:71-84. https://doi.org/10.1007/s1053 3-015-0140-1

10. Shiraki $Y$ (1964) Imbibitional swelling properties of clay-water system, Studies on clay-waters system, III-6. J Ceram Assoc Jpn 72:155-163. https://doi.org/10.2109/jcersj1950.72.826_155 (in Japanese with English abstract)

11. Yilmaz I, Marschalko M (2014) The effect of different types of water on the swelling behaviour of expansive clays. B Eng Geol Environ 73:1049-1062. https://doi.org/10.1007/s1006 4-014-0598-4

12. Bharat TV, Das DS (2017) Physicochemical approach for analyzing equilibrium volume of clay sediments in salt solutions. Appl Clay Sci 136:164-175. https://doi.org/10.1016/j.clay.2016.11.021

13. Zhu ZF, Xiong XZ, Liang $\mathrm{CH}$, Zhao M (2018) On the flocculation and settling characteristics of low- and high-concentration sediment suspensions: effects of particle concentration and salinity conditions. Environ Sci Pollut Res 25(14):14226-14243. https:// doi.org/10.1007/s11356-018-1668-0

14. WEPA (2020) Lake Kasumigaura. http://www.wepa-db.net/polic ies/cases/kasumigaura/01-1.htm/. Accessed 1 May 2020

15. Ishikawa T, Tanaka M (1993) Diurnal stratification and its effects on wind-induced currents and water qualities in Lake Kasumigaura, Japan. J Hydraul Res 31(3):307-322. https://doi. org/10.1080/00221689309498828

16. Fukushima T, Muraoka K (1981) Current and vertical mixing in a shallow lake. Verh Internat Verein Limnol 21:141-149

17. Havens KE, Fukushima T, Xie P, Iwakuma $T$, James RT, Takamura $\mathrm{N}$, Hanazato T, Yamamoto T (2001) Nutrient dynamics and the eutrophication of shallow lakes Kasumigaura (Japan), Donghu (PR China), and Okeechobee (USA). Environ Pollut 111:263-272. https://doi.org/10.1016/s0269-7491(00)00074-9

18. Seki T, Fukushima T, Imai A, Matsushige K (2006) Turbidity increase and sediment resuspension in Lake Kasumigaura. Proc JSCE G 62:122-134. https://doi.org/10.2208/jscejg.62.122 (in Japanese with English abstract)

19. Fukushima T, Kamiya K, Onda Y, Imai A, Matsushige $K$ (2010) Long-term changes in lake sediments and their influences on lake water quality in Japanese shallow lakes. Fund Appl Limnol 177:177-188. https://doi. org/10.1127/1863-9135/2010/0177-0177

20. Fukushima T, Komatsu E, Arai H, Kamiya K, Onda Y (2018) Shifts of radiocesium vertical profiles in sediments and their modelling in Japanese lakes. Sci Total Environ 615:741-750. https:// doi.org/10.1016/j.scitotenv.2017.09.286

21. Otsubo K, Aizaki M, Fukushima T, Iwata S, Muraoka K, Takamatsu T (1984) Characteristics of physical properties and nutrients distributions of mud in Lake Kasumigaura (1) Distributions of 
physical properties. Res Rep Nat Ins Environ Stud (NIES) 51:157189 (in Japanese with English abstract)

22. Ministry of Environment (2019) Sediment Survey Method, Ministry of Environment, Japan. http://www.env.go.jp/water/teish itsu-chousa/. Accessed 1 March 2019

23. National Institute for Environmental Studies (NIES) (2019) Lake Kasumigaura Database, National Institute Environmental Studies, Japan. http://db.cger.nies.go.jp/gem/inter/GEMS/database/ kasumi/index.html. Accessed 1 March 2019

24. Japan Meteorological Agency (JMA) (2019) Past meteorological data. http://www.data.jma.go.jp/obd/stats/etrn/. Accessed 1 March 2019

25. Vaughn CC, Hakenkamp CC (2001) The functional role of burrowing bivalves in freshwater ecosystems. Freshwat Biol 46(11):1431-1446. https://doi.org/10.104 6/j.1365-2427.2001.00771.x

26. Mulsow S, Landrum PF, Robbins JA (2002) Biological mixing responses to sublethal concentrations of DDT in sediments by Heteromastus filiformis using a Cs-137 marker layer technique. Mar Ecol Prog Ser 239:181-191. https://doi.org/10.3354/meps2 39181

27. Nakazato R, Tsuchiya T, Muramatsu M, Higo M, Sakurai H, Saji A, Naya T (2005) Horizontal distribution and long-term trends in population densities of chironomid larvae in Lake Kitaura, Ibaraki Prefecture, Japan. Jpn J Limnol 66:165-180. https:// doi.org/10.3739/rikusui.66.165 (in Japanese with English abstract)

28. Matsuzaki S, Takamura N, Arayama K, Tominaga A, Iwasaki J, Washitani I (2011) Potential impacts of non-native channel catfish on commercially important species in a Japanese lake, as inferred from long-term monitoring data. Aqua Conserv Mar Freshw Ecosyst 21:348-358. https://doi.org/10.1002/aqc.1198

29. Avnimelech Y, Ritvo G, Meijer LE, Kochba M (2001) Water content, organic carbon and dry bulk density in flooded sediments.
Aquacult Eng 25(1):25-33. https://doi.org/10.1016/s0144 -8609(01)00068-1

30. Aizaki M, Nakajima T (1981) Characteristics of bacterial distribution related to nutrient dynamics in Lake Kasumigaura. Res Rep Nat Ins Environ Stud (NIES) 22:62-87 (in Japanese with English abstract)

31. Fukushima T, Takahashi M, Matsushita B, Okanishi Y (2007) Land use/cover change and its drivers: a case in the watershed of Lake Kasumigaura, Japan. Landscape Ecol Eng 3:21-31. https://doi. org/10.1007/s11355-006-0008-6

32. Yang F, Matsushita B, Fukushima T (2010) A pre-screened and normalized multiple endmember spectral mixture analysis for mapping impervious surface area in Lake Kasumigaura Basin, Japan. ISPRS J Photogramm Remote Sens 65:479-490. https:// doi.org/10.1016/j.isprsjprs.2010.06.004

33. Ebise $S$ (1984) Analysis on basic unit of runoff loading classified by land use in river basin. Res Rep Nat Ins Environ Stud (NIES) 50:81-102 (in Japanese with English abstract)

34. Ebise $S$ (1984) Estimation of total pollutant loading by all influent rivers into Lake Kasumigaura. Res Rep Nat Ins Environ Stud (NIES) 50:41-58 (in Japanese with English abstract)

35. Murata K (2004) Measurement method of sea-salt particles. In: The 3rd general report of the Ibaraki Nature Museum, pp 109-112 (in Japanese)

36. Sugita M, Ikura H, Miyano A, Yamamoto K, Wei ZW (2014) Evaporation from Lake Kasumigaura: annual totals and variability in time and space. Hydrol Res Lett 8(3):103-107. https://doi. org/10.3178/hrl.8.103

Publisher's Note Springer Nature remains neutral with regard to jurisdictional claims in published maps and institutional affiliations. 